\title{
Pendugaan Potensi Volume Akuifer Menggunakan Metode Geolistrik di Pulau Gili Ketapang, Probolinggo, Jawa Timur
}

\author{
Estimating Aquifer Volume Potency Using Geoelectric Method in Gili \\ Ketapang Island, Probolinggo, East Java
}

\author{
Dino Gunawan Pryambodo dan Joko Prihantono \\ Pusat Penelitian dan Pengembangan Sumber Daya Laut dan Pesisir, KKP \\ Jl. Pasir Putih 1, Ancol Timur, Jakarta, Indonesia, 14430 \\ *E-mail: dinogunawan77@gmail.com
}

Naskah diterima: 29 April 2019, direvisi: 21 Mei 2019, disetujui: 28 Mei 2019

DOI: $\underline{10.17146 / \text { eksplorium.2019.40.1.5415 }}$

\begin{abstract}
ABSTRAK
Pengukuran geolistrik dengan menggunakan konfigurasi schlumberger telah dilakukan di Pulau Gili Ketapang, sebuah pulau kecil yang memiliki kepadatan penduduk mencapai $12.356 \mathrm{jiwa} / \mathrm{km}^{2}$. Pengukuran dilakukan di 8 lokasi menggunakan metode pada 8 titik Vertical Electrical Sounding (VES). Hasil pengolahan data geolistrik menunjukkan nilai tahanan jenis akuifer berkisar antara 2,71-206 $\Omega \mathrm{m}$ pada litologi batugamping pasiran. Potensi volume akuifer terbesar berdasarkan model 2D akuifer air tanah berada di lokasi K-03 dan K-17. Model 3D akuifer air tanah menunjukkan bahwa volume akuifer sebesar $27.689 .400 \mathrm{~m}^{3}$ atau sekitar 27.689.400.000 liter. Air tanah di dalam akuifer dapat bertahan selama 68 tahun jika tidak terjadi kenaikan populasi. Selain itu, air tanah juga akan bertahan meskipun tidak terjadi penambahan air di dalam akuifer, baik secara alami ataupun buatan.
\end{abstract}

Kata kunci: geolistrik, volume, akuifer, schlumberger

\begin{abstract}
Geoelectric measurement using Schlumberger configuration was carried out in Gili Ketapang Island, a small island with a population density of 12,356 people/km2. The measurement conducted at 8 locations using a vertical electrical sounding (VES) method. The result of geoelectric data processing shows aquifer resistivity value ranging from 2.71-206 $\Omega m$ at the sandy limestone lithology. The largest aquifer volume potency based on the $2 D$ groundwater aquifer model is in the K-03 and K-17 location. The $3 D$ groundwater aquifer model shows that the aquifer volume is 27,689,400 $\mathrm{m3}$ or about 27.689.400.000 liters. The groundwater inside the aquifer will last within 68 years in a condition where there is no population increase. Besides, the groundwater also lasts even there is no water addition inside the aquifer, by natural or artificial.
\end{abstract}

Keywords: geoelectric, volume, aquifer, schlumberger

\section{PENDAHULUAN}

Pulau kecil merupakan pulau yang memiliki keanekaragaman yang spesifik, sumber daya alam yang terbatas, dan masyarakat yang memiliki karakteristik sosial budaya yang beradaptasi dengan kehidupan pulau. Ekosistem kepulauan memiliki karakteristik berupa keterbatasan daya dukung lingkungan baik lahan maupun air sebagai kebutuhan dasar.

Air bersih merupakan salah satu kebutuhan bagi kehidupan manusia. Keberlangsungan hidup manusia sejalan dengan adanya ketersediaan air bersih di tempat manusia itu berada. Permasalahan air bersih akhir-akhir ini sangat kompleks seiring dengan bertambahnya jumlah penduduk di 
suatu tempat dan aktivitas manusia yang semakin beragam dalam penggunaan air bersih. Pengalihfungsian lahan yang tidak sesuai peruntukannya mengakibatkan ketesediaan air bersih terutama air tanah semakin berkurang. Sumber daya air di pulau-pulau kecil bisa berupa air permukaan, air tanah, dan air atmosferik (hujan). Air tanah merupakan salah satu sumber utama air tawar di wilayah pulau-pulau kecil [1].

Pulau Gili Ketapang (Gambar 1) termasuk dalam wilayah Kabupaten Probolinggo, Provinsi Jawa Timur. Pulau Gili Ketapang memiliki luas 68 ha. Berdasarkan PERMEN Perikanan dan Kelautan No. 20 Tahun 2008, suatu pulau dapat dikatakan sebagai Pulau Kecil apabila memiliki luas kurang dari $2.000 \mathrm{~km}^{2}$ [2]. Oleh karena itu, Pulau Gili Ketapang yang memiliki luas 68 ha atau $0,68 \mathrm{~km}^{2}$ termasuk kategori Pulau
Kecil. Dengan jumlah penduduk mencapai 8.583 jiwa [3] menjadikan Pulau Gili Ketapang menjadi salah satu pulau kecil yang berpenduduk padat menurut Undang-undang Nomor 56/PRP/1960 [4] dengan kepadatan mencapai $12.356 \mathrm{jiwa} / \mathrm{km}^{2}$

Metode geolistrik konfigurasi schlumberger adalah salah satu metode geofisika yang dapat digunakan untuk memetakan bagian bawah permukaan tanah melalui sifat kelistrikan batuan[5]. Dari hasil pemetaan bawah permukaan ini dapat diperkirakan keberadaan sebaran air tanah di Pulau Gili Ketapang. Dengan mengetahui sebaran air tanah di pulau tersebut maka dapat diperoleh informasi-informasi tambahan untuk pengelolaan air tanah secara berkelanjutan di Pulau Gili Ketapang.

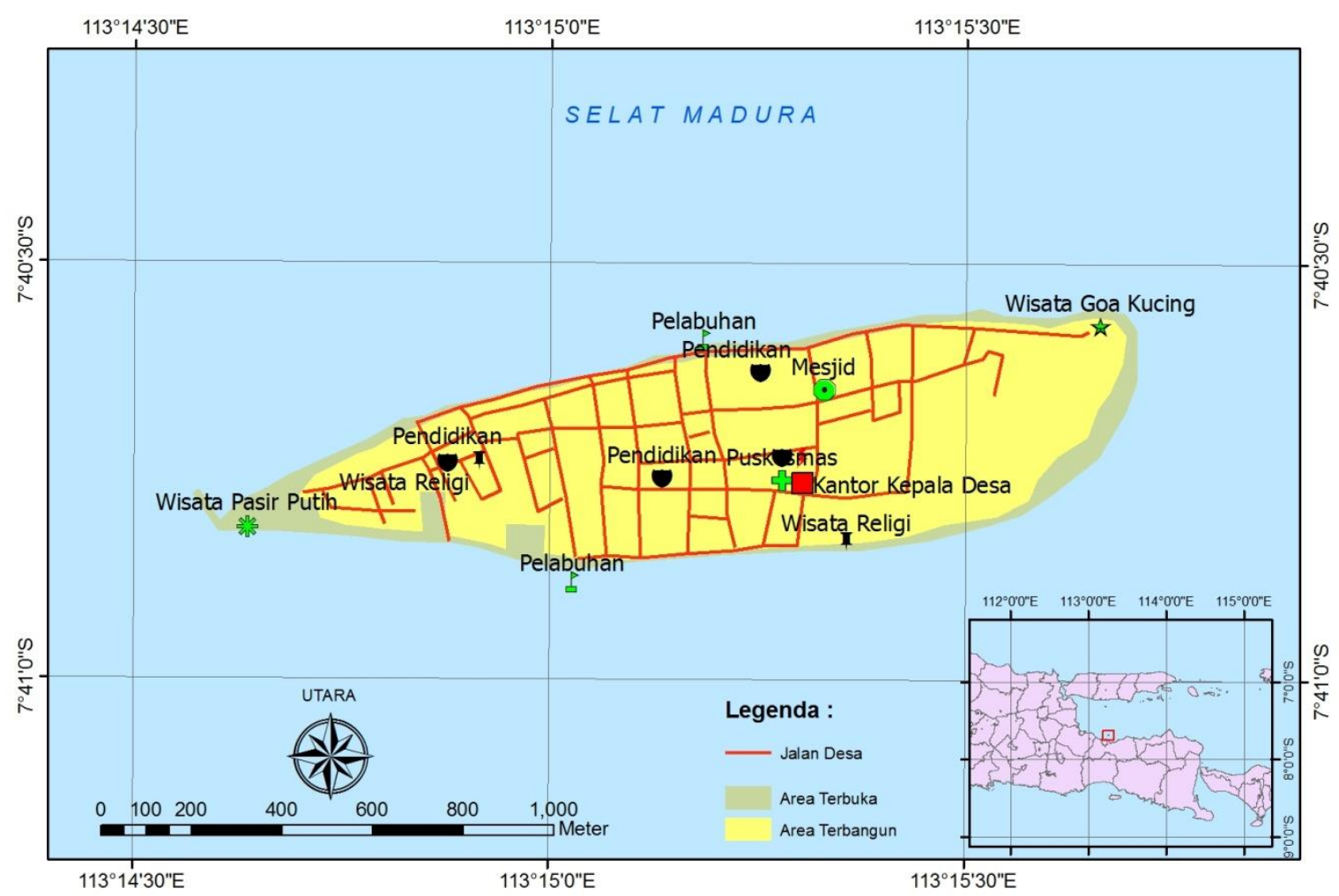

Gambar 1. Peta lokasi penelitian. 


\section{METODE GEOLISTRIK}

Pengukuran

geofisika

dengan

menggunakan metode resistivitas (geolistrik) bertujuan untuk memperoleh nilai resistivitas batuan/medium bawah permukaan bumi [6]. Metode geolistrik konfigurasi schlumberger dilakukan dengan cara menginjeksikan arus dan mengukur tegangan atau potensial yang terbaca di permukaan, sehingga diperoleh nilai resistivitas atau tahanan jenis antarlapisan batuan di bawah permukaan bumi. Nilai resistivitas yang terbaca digunakan sebagai dasar penafsiran litologi/batuan bawah permukaan. Prinsip dasar metode geolistrik resistivitas adalah Hukum Ohm. Nilai resistivitas diperoleh dengan mengukur nilai beda potensial dari 2 elektoda potensial, dan arus yang dilewatkan pada suatu penghantar (elektoda arus) [7] (Gambar 2).

Susunan elektroda pada metode geolistrik konfigurasi schlumberger ditunjukan pada Gambar 3. Pengukuran pada suatu titik sounding dilakukan dengan melakukan variasi jarak elektroda. Variasi jarak elektroda dilakukan mulai dari jarak elektroda terdekat kemudian semakin menjauh secara gradual Jarak elektroda sebanding dengan kedalaman lapisan batuan yang dapat diselidiki. Pada pengukuran sebenarnya, penambahan jarak antarelektroda mungkin dilakukan jika mempunyai suatu alat geolistrik yang memadai. Dalam hal ini alat geolistrik tersebut harus dapat menghasilkan arus listrik yang cukup besar atau alat tersebut harus cukup sensitif dalam mendeteksi benda potensial yang kecil sekali. Oleh karena itu, alat geolistrik yang baik adalah alat yang dapat menghasilkan arus listrik cukup besar dan mempunyai sensitivitas yang cukup tinggi.

Konfigurasi schlumberger termasuk konfigurasi elektroda yang sering digunakan dalam dalam vertical electrical sounding (VES). Data yang diperoleh dari metode ini mampu mencapai kedalaman yang besar [8].

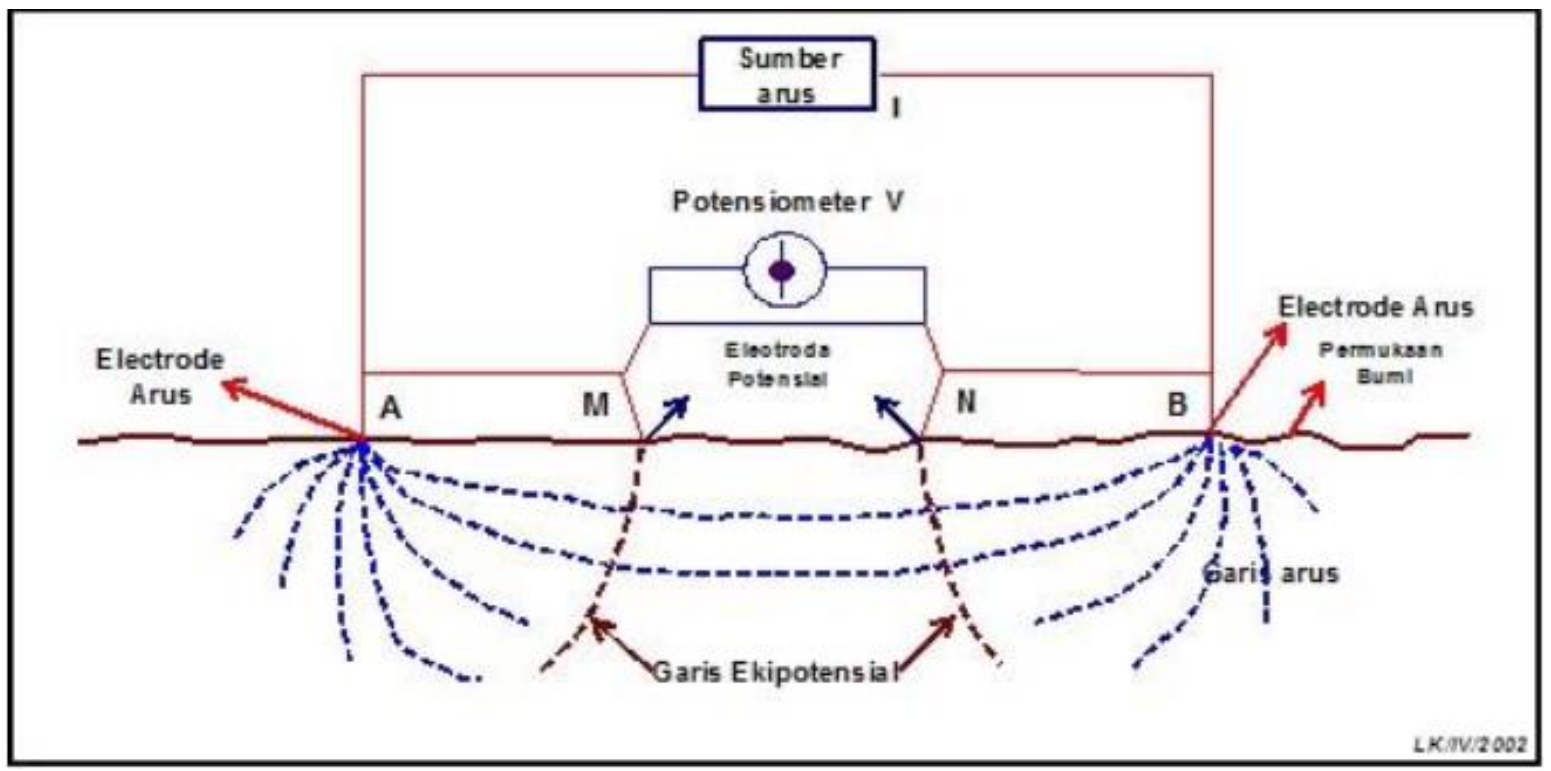

Gambar 2. Penjalaran arus listrik dalam pengukuran geolistrik. 


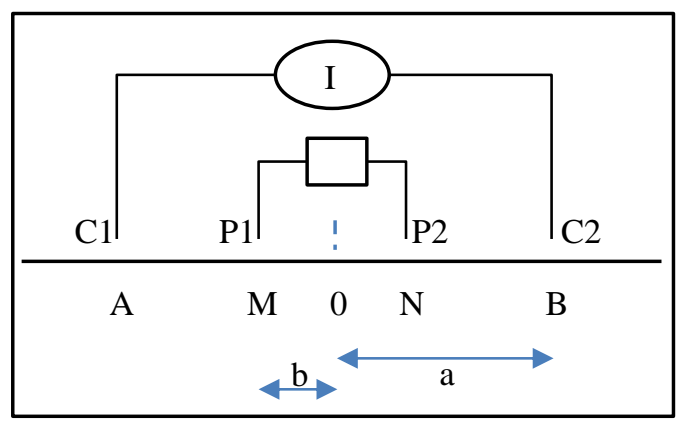

Gambar 3. Rangkaian elektroda konfigurasi schlumberger.

Hubungan antara resistivitas $(\rho)$, beda potensial $(\Delta V)$, dan arus $(I)$ pada VES dengan konfigurasi elektroda schlumberger ditunjukkan dengan persamaan berikut [9]:

$\rho=\frac{\pi\left(a^{2}-b^{2}\right)}{2 b} \frac{\Delta V}{I}$

dengan $a$ adalah jarak setengah jarak antarelektoda arus $\mathrm{C} 1 \mathrm{C} 2$ dan $b$ adalah setengah jarak antarelektroda potensial P1P2.

Peningkatan konsentrasi ion pada fluida akan meningkatkan konduktifitas fluida dan menurunkan nilai resistivitas batuan secara keseluruhan [10]. Satuan resistivitas yang digunakan adalah Ohm.meter $(\Omega \mathrm{m})$. Beberapa penelitian terdahulu membuktikan bahwa pengaruh kandungan air dapat menurunkan nilai resistivitas suatu batuan. Besar penurunan nilai resistivitas tergantung pada kandungan air yang ada di dalam poripori batuan (porositas batuan) [11]. Secara teoritis setiap batuan memiliki daya hantar listrik dan nilai resistivitas masing-masing. Batuan yang sama belum tentu mempunyai nilai resistivitas yang sama. Sebaliknya nilai resistivitas sama bisa dimiliki oleh batuanbatuan yang berbeda.
Faktor-faktor yang mempengaruhi nilai resistivitas antara lain: komposisi litologi, kondisi batuan, komposisi mineral, kandungan benda cair, dan faktor eksternal lainnya [12]. Pada batuan sedimen, batuan yang bersifat lepas, mempunyai nilai resistivitas lebih rendah bila dibandingkan dengan batuan sedimen padu dan kompak sedangkan batuan beku dan batuan metamorf mempunyai nilai resistivitas yang tergolong tinggi. Batuan yang basah dan mengandung air memiliki nilai resistivitas rendah dan semakin rendah bila air bersifat payau atau asin. Selain fakor komposisi dan karakter batuan, faktor eksternal seperti kabel, tiang listrik, dan saluran pipa logam juga dapat mempengaruhi hasil pengukuran di lapangan.

\section{GEOLOGI DAN HIDROGRAFI PULAU GILI KETAPANG}

Daerah penelitian di Pulau Gili Ketapang tersusun atas litologi batuan sedimen dan endapan permukaan aluvial yang berumur Kuarter [13]. Litologi tertua di lokasi penelitian merupakan batugamping koral dan batugamping pasiran. Di atas batugamping tersebut terendapkan secara selaras endapan aluvium berupa endapan campuran lempung, lumpur, pasir, kerikil, kerakal, bongkah, dan sisa tanaman.

Secara umum, daerah penelitian Pulau Gili Ketapang tersusun atas batugamping dan diperkirakan memiliki karakteristik pola hidrogeologi yang mirip dengan hidrogeologi kawasan karst. Proses-proses eksogen pelarutan umum dijumpai pada litologi batugamping yang membentuk conduit (rongga-rongga) dan berakhir pada pembentukan sungai-sungai bawah tanah. 
Dengan demikian, rongga-rongga resapan menjadi penting untuk memelihara kelangsungan air tanah di daerah batugamping. Adanya soil dan tutupan lain menyebabkan tersumbatnya aliran air tanah meresap lebih dalam, dan air tanah lebih banyak dijumpai di permukaan [14].

\section{HASIL}

Pengukuran VES telah dilakukan pada 8 titik yang tersebar di Pulau Gili Ketapang, Probolinggo Jawa Timur (Gambar 4). Tiap titik pengukuran memiliki kedalaman $100 \mathrm{~m}$ di bawah permukaan tanah.

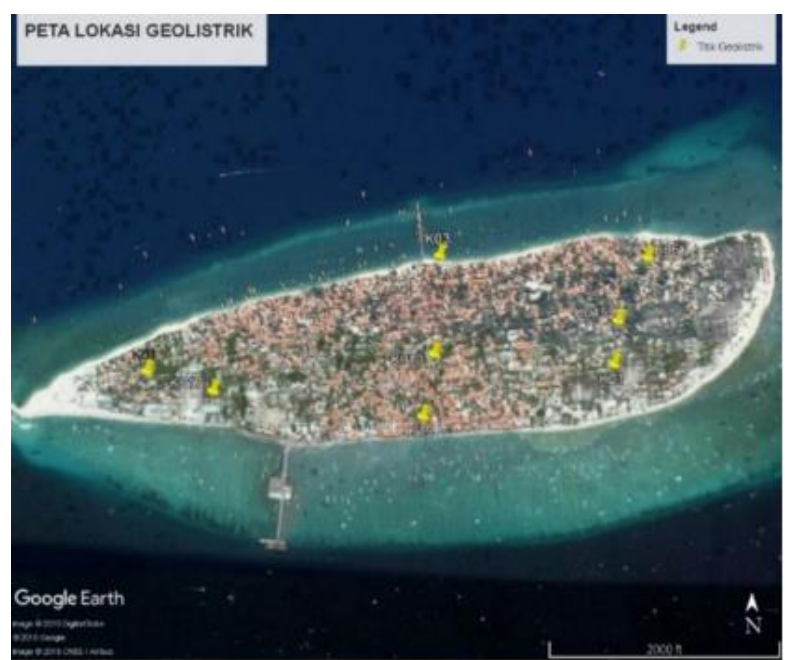

Gambar 4. Titik pengukuran geolistrik di Pulau Gili Ketapang.

Dari hasil pengukuran geolistrik di Pulau Gili Ketapang diketahui nilai resistivitas batuan yang diinterpretasikan ke dalam satuan litologi seperti pada Tabel 1.

Tabel 1. Nilai resistiviitas hasil pengukuran geolistrik di Pulau Gili Ketapang

\begin{tabular}{lll}
\hline No & Nilai Resistivitas $(\Omega \mathrm{m})$ & Litologi \\
\hline 1 & $11,3-59$ & aluvial (akuifer) \\
2 & $71-106$ & batupasir (air tanah) \\
3 & $139-68.198$ & batugamping \\
\hline
\end{tabular}

Berdasarkan hasil interpretasi nilai resistivitas geolistrik pada Tabel 1, maka diperoleh gambaran litologi pada 8 titik pengukuran geolistrik di Pulau Gili Ketapang (Gambar 5).

Analisis penampang bawah permukaan dilakukan dengan membuat 3 lintasan berdasarkan 8 titik pengukuran VES yang telah dilakukan. Lintasan 1 melewati titik K06, K-15, dan K-21. Lintasan 2 melewati titik K-3, K-13, K-19 dan Lintasan 3 melewai titik K-01, K-17,K-13, dan K-19.

\section{Lintasan 1 (K-06, K-15, dan K-21)}

Lintasan 1 berarah utara-selatan dengan panjang lintasan sejauh 306 meter (Gambar 6). Lintasan ini terletak di bagian timur Pulau Gili Ketapang yang secara umum memiliki singkapan-singkapan batugamping.

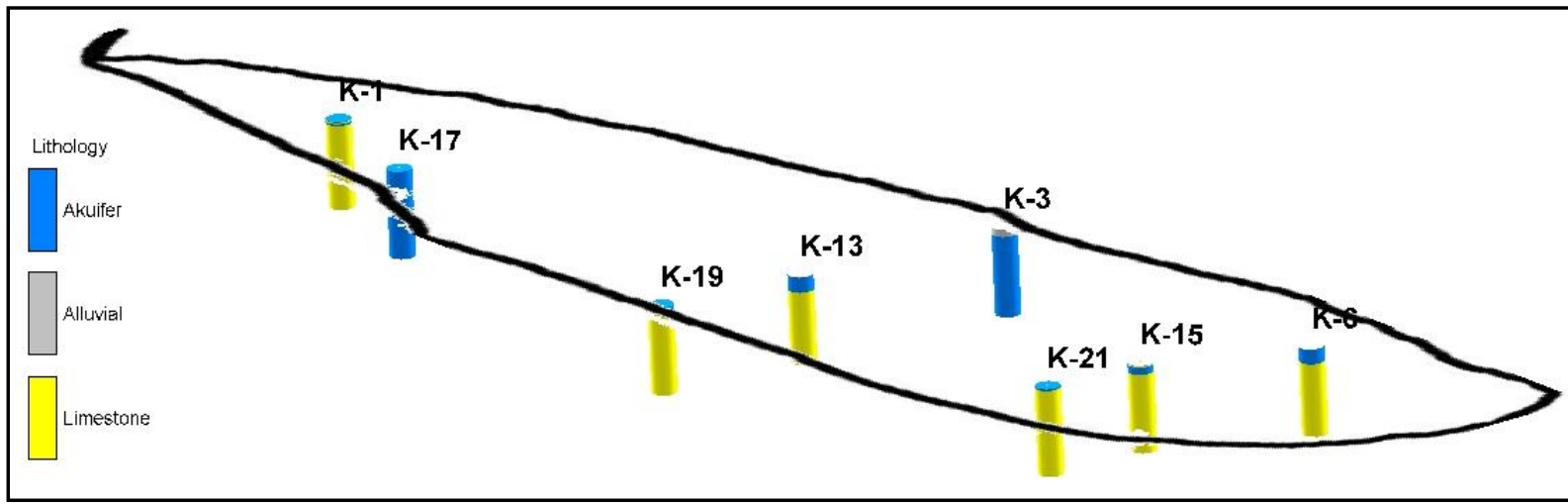

Gambar 5. Hasil intrepretasi pengukuran geolistrik di Pulau Gili Ketapang. 


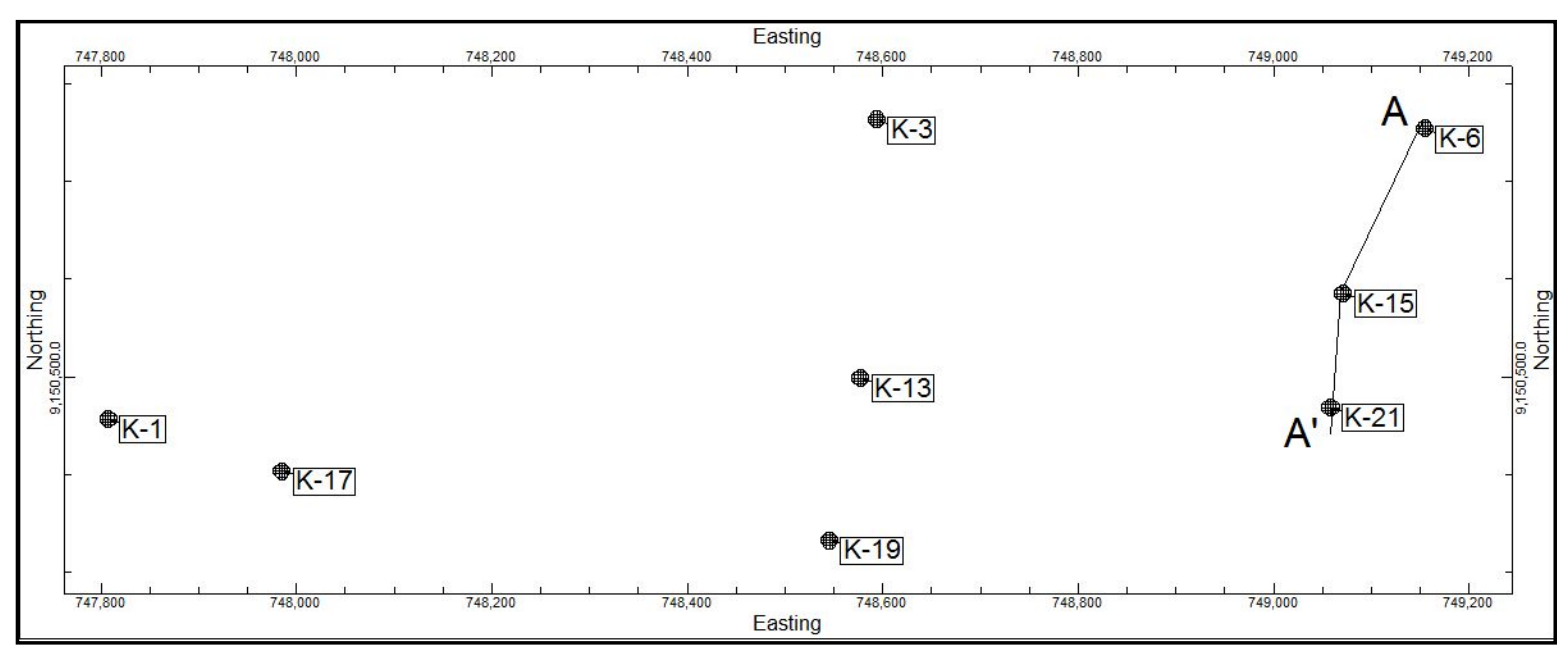

Gambar 6. Lintasan 1 (K-06, K-15, dan K-21).

Penampang model bawah tanah dari lintasan 1 ditunjukkan pada Gambar 7. Pada lintasan 1 dapat diidentifikasi adanya akuifer di beberapa tempat. Pada titik K-06, akuifer terdapat pada kedalaman 0-18 meter di bawah permukaan tanah. Tebal akuifer pada lintasan ini semakin menipis ke arah selatan sehingga pada titik K-15 akuifer terdapat pada kedalaman 0-10 meter di bawah permukaan tanah. Pada titik K-21 keberadaan akuifer sudah tidak terlihat lagi dikarenakan pada daerah di sekitar titik K-21 didominasi oleh batugamping yang keras dan endapan aluvial sebagai penutup (top soil) dari batugamping tersebut. Akuifer pada lintasan 1 melampar dari titik K-06 ke arah selatan dengan jarak mencapai 260 meter.

\section{Lintasan 2 (K-03, K-13, dan K-19)}

Lintasan 2 terletak di bagian tengah Pulau Gili Ketapang. Lintasan 2 berarah utara-selatan dengan panjang lintasan sejauh 436 meter (Gambar 8).

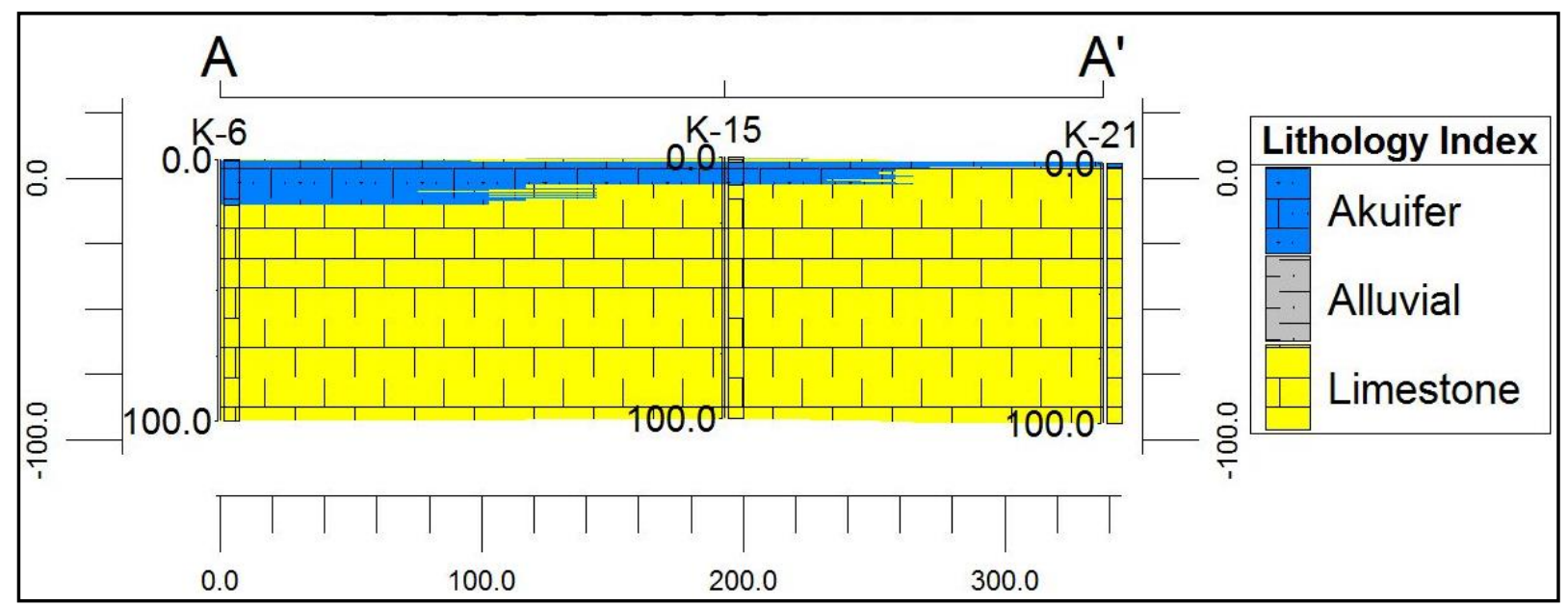

Gambar 7. Penampang Lintasan 1 (K-06, K-15, dan K-21). 


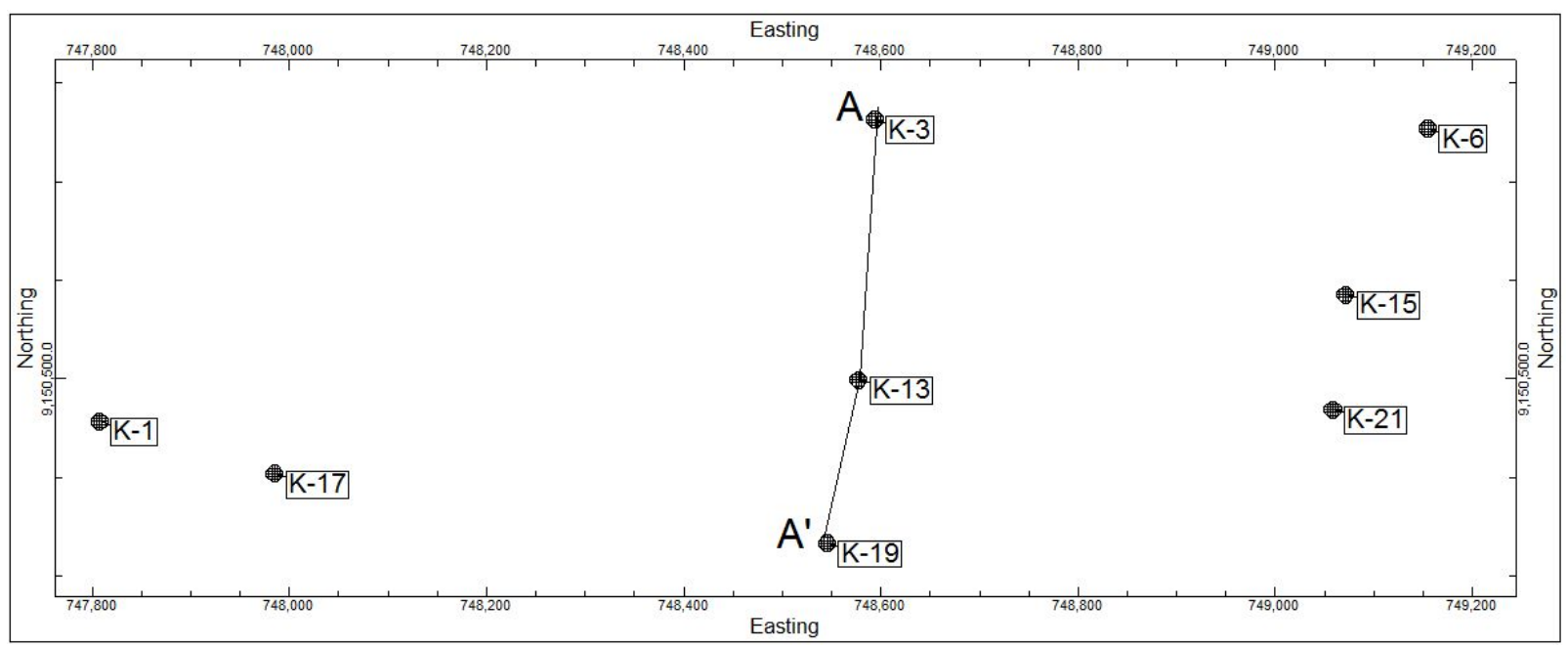

Gambar 8. Lintasan 2 (K-03, K-13, dan K-19).

Penampang bawah permukaan lintasan 2 menunjukkan adanya akuifer yang cukup besar (Gambar 9). Pada titik K-0, kedalaman akuifer berada antara 8-100 meter di bawah permukaan tanah. Pada bagian atas dari akuifer tersebut terdapat lapisan aluvial hingga ke permukaan. Pada titik K-13, akuifer air tanah terdapat pada kedalaman antara 0-18 meter di bawah permukaan tanah. Pada kedalaman lebih dari 18 meter teramati adanya batugamping yang keras. Ketebalan akuifer pada lintasan ini semakin menipis ke arah titik K-19. Pada titik K-19, akuifer terdapat pada kedalaman antara 0-7 meter di bawah permukaan tanah. Secara umum keberadaan akuifer pada lintasan 2 ini makin menipis kearah selatan (A') karena pada bagian selatan Pulau Gili Ketapang didominasi oleh batugamping yang juga terlihat sebagai singkapan-singkapan di atas permukaan tanah.

\section{Lintasan 3 (K-01, K-17, K-13, dan K-15)}

Lintasan 3 terletak berada di bagian barat Pulau Gili Ketapang (Gambar 10). Lintasan ini memanjang dengan arah lintasan barattimur dan merupakan lintasan terpanjang dengan panjang lintasan mencapai 1.340 meter.

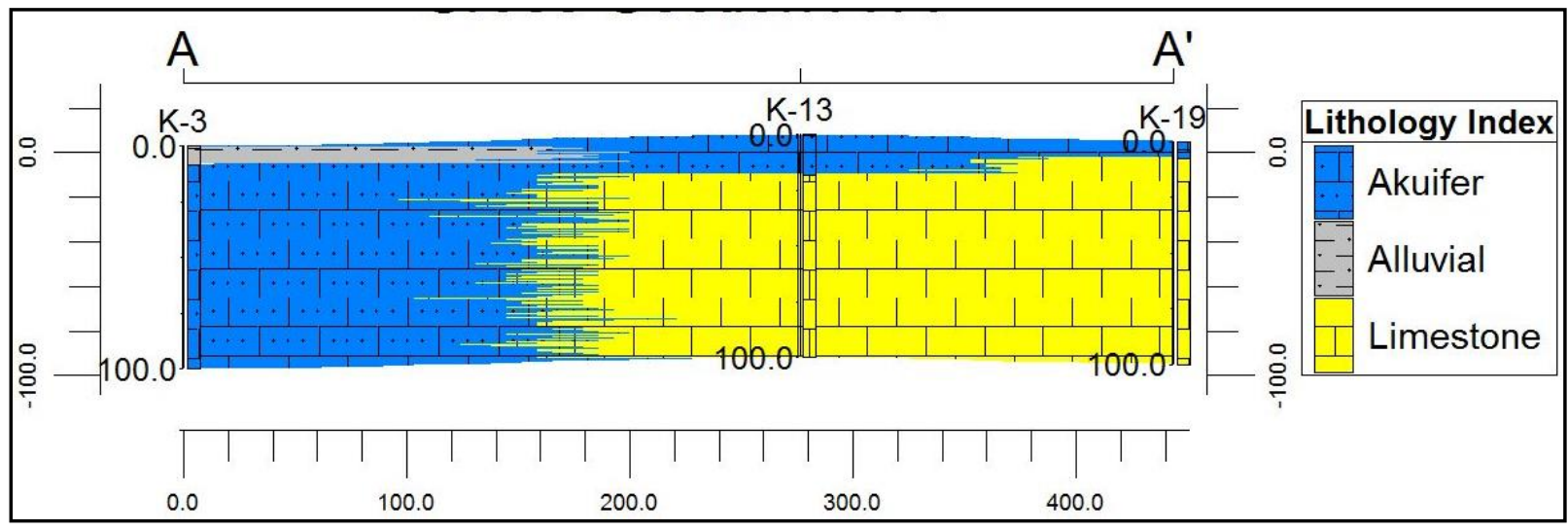


Gambar 9. Penampang Lintasan 2 (K-03, K-13, dan K-19).

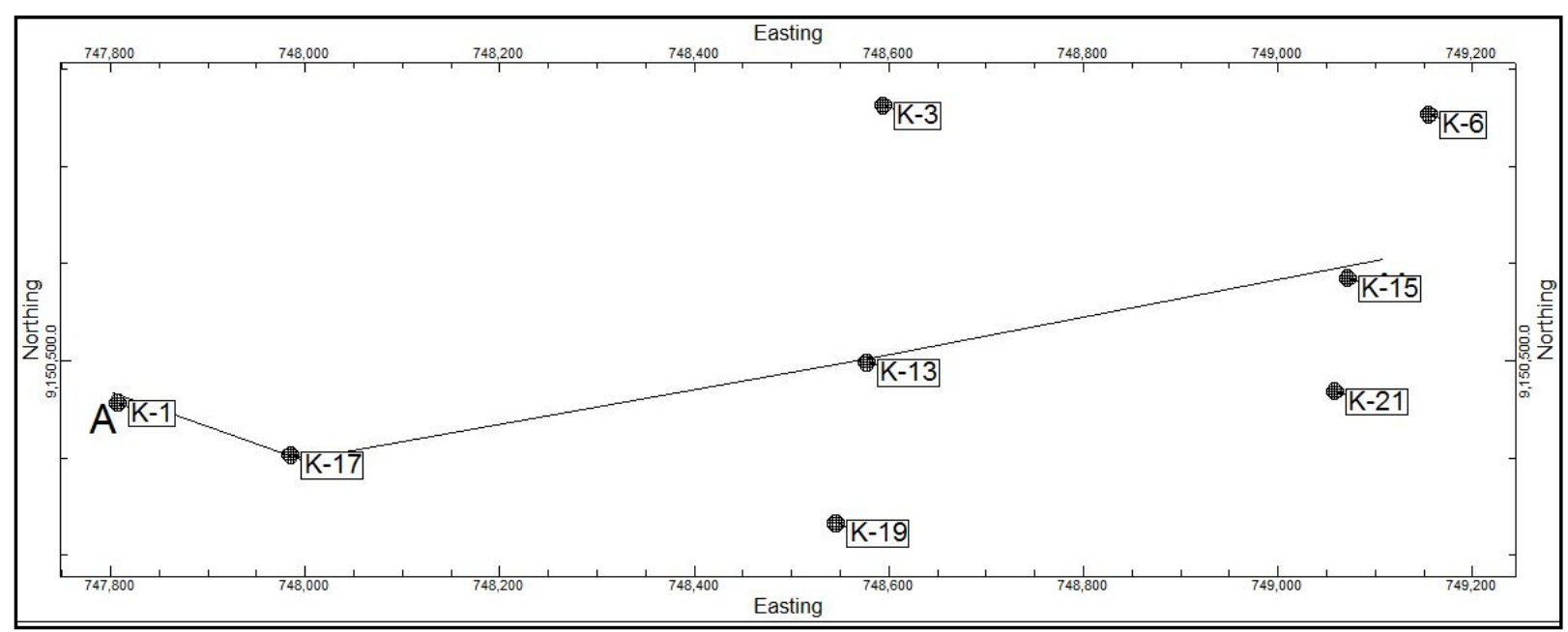

Gambar 10. Lintasan 3 (K-01, K-17, K-13, dan K-19).

Penampang bawah permukaan dari Lintasan 3 ditunjukkan pada Gambar 11. Pada lintasan ini teramati bahwa titik K-17 memiliki potensi akuifer terbanyak. Pada titik tersebut, akuifer berada pada kedalaman 0100 meter dari atas permukaan tanah dengan panjang akuifer mencapai 350 meter. Pelamparan akuifer ini makin ke arah timur makin menipis karena di bagian timur Pulau Gili Ketapang didominasi oleh batugamping, hal ini diperkuat dengan singkapan batugamping yang muncul di atas permukaan.

Berdasarkan ketiga model penampang 2D (Gambar 7, 9, dan 11), dibuat model penampang 3D untuk mengetahui persebaran akuifer di bawah permukaan tanah di pulau tersebut (Gambar 12). Hasil 3D akuifer di Pulau Gili Ketapang menunjukkan volume akuifer yang setara dengan volume air tanah sebesar 27.689.400 $\mathrm{m}^{3}$ atau sekitar 27.689.400.000 liter. Titik K-03 dan K-17 memiliki potensi volume akuifer yang paling besar seperti terlihat pada penampang model 2D.

Desa Gili Ketapang memiliki jumlah penduduk sebesar 8.583 jiwa dengan jumlah Rumah Tangga 1.614 KK. Kebutuhan air penduduk pedesaan adalah 130 liter per orang per hari [15], maka kebutuhan air di pulau tersebut sebanyak 1.095.120 liter/hari.

Berdasarkan angka kebutuhan tersebut, maka volume air tanah yang tersedia di dalam akuifer Pulau Gili Ketapang akan habis dalam 68 tahun dengan asumsi tidak ada penambahan jumlah penduduk dan penambahan volume air ke dalam akuifer secara alami maupun buatan.

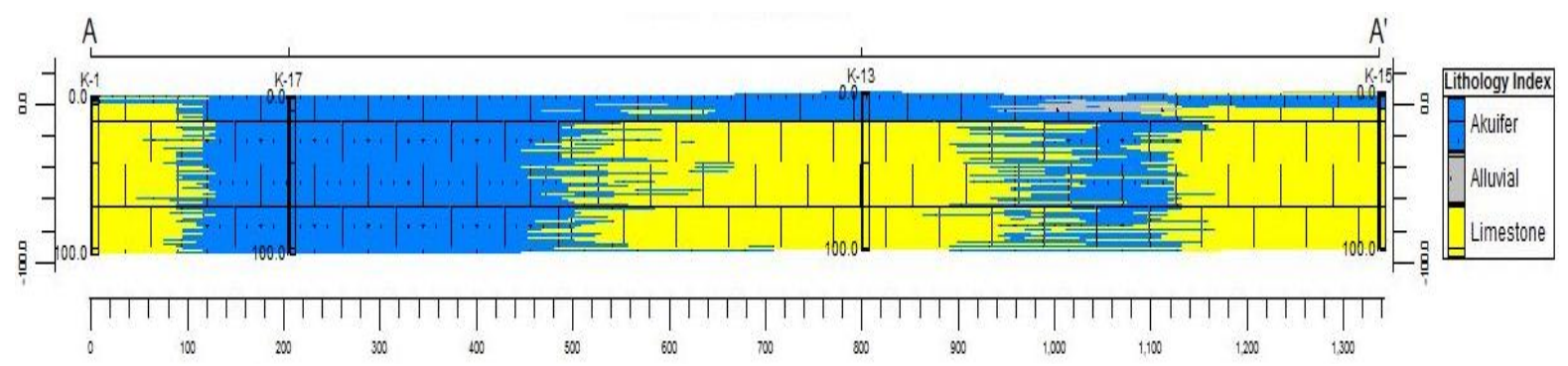


Gambar 11. Penampang Lintasan 3 (K-01, K-17,K-13, dan K-19).

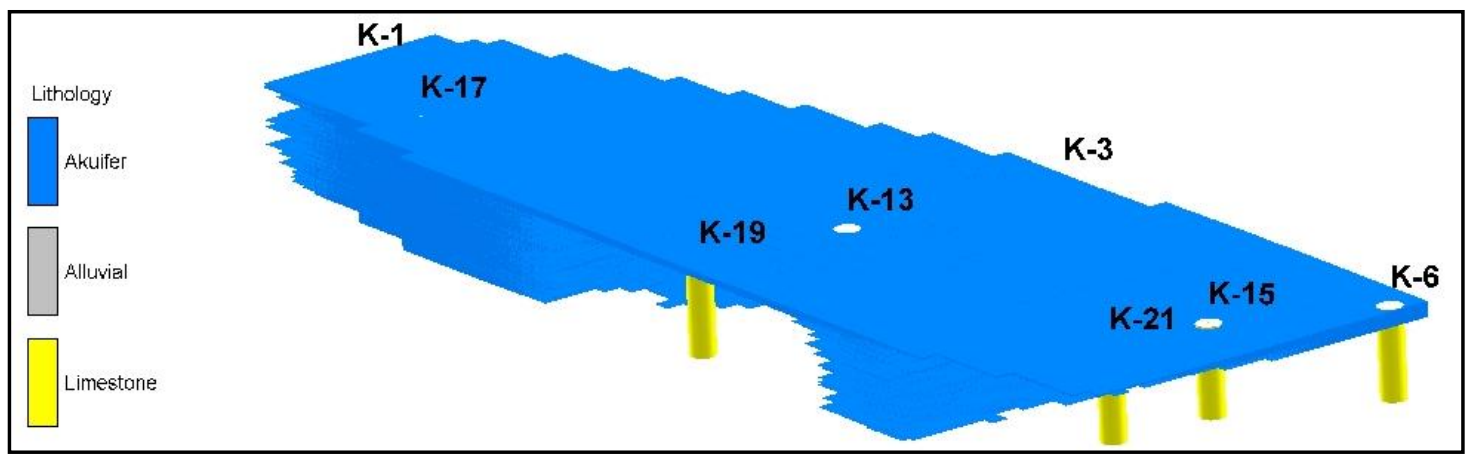

Gambar 12. Model 3D akuifer di Pulau Gili Ketapang.

\section{KESIMPULAN}

Pengukuran geolistrik konfigurasi schlumberger di Pulau Gili Ketapang telah dilakukan pada 8 titik pengukuran dengan dengan kedalaman pengukuran 100 meter di bawah permukaan tanah. Nilai resistivitas menunjukkan litologi berupa aluvial, batupasir, dan batugamping. Sebaran akuifer bawah tanah di pulau tersebut dilakukan dengan analisis penampang 2D dan 3D. Hasil pemodelan 3D menunjukkan bahwa Pulau Gili Ketapang memiliki volume akuifer sebesar 27.689.400 $\mathrm{m}^{3}$ atau sekitar 27.689.400.000 liter. Volume air tanah di Pulau Gili Ketapang tersebut cukup untuk memenuhi kebutuhan penduduk hingga jangka waktu 68 tahun mendatang.

\section{DAFTAR PUSTAKA}

[1] A. Susilawaty, M. Amansyah, dan Nildawati, "Kerentanan Ketersediaan Air Bersih di Daerah Pesisir dan Pulau-Pulau Kecil Sulawesi Selatan Indonesia," Al-Sihah: Public Health Science Journal, vol. 8, no. 2, 2016.

[2] Yulius dan H. L. Salim, “Aplikasi GPS dalam Penentuan Posisi Pulau di Tengah Laut Berdasarkan Metode Toponimi (Studi Kasus Pulau Morotai dan Sekitarnya)", Jurnal Saintek Perikanan, vol. 9, no. 2, 2014

[3] A. R. Saputera dan Hasanudin, "Desain Kapal Penyebrangan Sebagai Sarana Transpotasi, Rekreasi, dan Edukasi di Pulau Gili Ketapang,
Probolinggo, Jawa Timur," Jurnal Teknik ITS, vol. 6, no. 2, 2017.

[4] PERPU No. 56, Penetapan Luas Tanah Pertanian, 1960

[5] S. Amien, "Penyelidikan Hidrogeologi dengan Metode Geolistrik Schlumberger di Kecamatan Hamparan Perak, Deli Serdang, Sumatera Utara," Journal of Electrical Technology, vol. 1, no. 2, 2016.

[6] Hakim dan R. H. Manrulu, “Aplikasi Konfigurasi Wenner dalam Menganalisa Jenis Material Bawah Permukaan", Jurnal Ilmiah Pendidikan Fisika Al-BiRuNi, vol. 5, no. 1, 2016.

[7] G. S. Huraju, As'ari, dan S. H. J. Tongkukut, "Identifikasi Patahan Manado dengan Menggunakan Metode Geolistrik Konfigurasi Wenner di Kota Manado," Jurnal Ilmiah Sains, vol. 15, no. 2, 2015.

[8] R. Bharti, "The Vertical Electrical Sounding (VES) Procedure to Delineate Potential Groundwater Aquifers in Guna Madhya Pradesh," Imperial Journal of Interdisciplinary Research, vol. 2, hal. 253-256, 2016.

[9] T. N. Fitrianto, Supriyadi, U. A. Taufiq, T. M. Mukromin, dan A. P. Wardana, "Identifikasi Potensi Air Tanah Menggunakan Metode Geolistrik Resistivitas Konfigurasi Schlumberger di Kelurahan Bapangsari Kecamatan Bagelen Kabupaten Purworejo," Jurnal Fisika Flux, vol. 15, no. 2, 2018.

[10] M. Hasanudin dan D. G. Pryambodo, "Studi Intrusi Air Laut di Cirebon dengan Menggunakan Metode Geolistrik," Jurnal Segara, vol. 5, 2009.

[11] D. G. Pryambodo, J. Pihantono, R. A. Troa, dan E. Triarso, "Identifikasi Akuifer Dangkal di Pulau Terdepan NKRI dengan Menggunakan 
Metode Geolistrik 2D: Studi Kasus Pulau Laut, Kab. Natuna," Eksplorium, vol. 37, no. 2, 2016.

[12] B. Soenarto, "Penyusupan Air Asin Dalam Cekungan Air Tanah Jakarta," Jurnal Penelitian dan Pengembangan Pengairan, no. 8, 1988.

[13] Suharsono dan T. Suwarti, Peta Geologi Lembar Probolinggo, Bandung: Puslitbang Geologi, 1992.
[14] Sulastoro, "Karakteristik Sumber daya Air di Daerah Karst (Studi Kasus Daerah Pracimantoro)," Journal of Rural and Development, vol. 4, no. 1, 2013.

[15] H. Poediastoeti, "Pengaruh Kondisi Sosial Ekonomi Masyarakat Terhadap Pola Pemakaian Air Domestik," Jurnal Lingkungan-Sultan Agung, vol. 1, no. 1, 2013. 